\title{
Asymmetric propionate aldol reactions of a chiral lithium enolate accessible from direct enolization with $n$-butyllithium
}

\author{
Claudio Palomo, ${ }^{\dagger}$ Mikel Oiarbide, $^{\dagger}$ Enrique Gómez-Bengoa, ${ }^{\dagger}$ Antonia Mielgo, ${ }^{\dagger}$

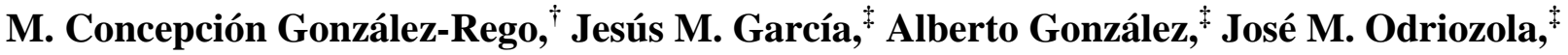 \\ Patricia Bañuelos, ${ }^{\ddagger}$ and Anthony Linden ${ }^{\S}$
}

${ }^{\dagger}$ Departamento de Química Orgánica I, Facultad de Química, Universidad del País Vasco, Apdo. 1072, 20080-San Sebastián, Spain; ${ }^{\ddagger}$ Departamento de Química Aplicada, Universidad Pública de Navarra, Campus de Arrosadía, 31006-Pamplona, Spain; ${ }^{\S}$ Organisch-Chemisches Institut der Universität Zürich, Winterthurerstrasse-190, CH-8057, Zürich, Switzerland (X-ray) E-mail:qoppanic@sc.ehu.es

Dedicated to Prof. Eusebio Juaristi on the occasion of his $55^{\text {th }}$ birthday (received 14 Jun 05; accepted 12 Aug 05; published on the web 22 Aug 05)

\begin{abstract}
The presented lithium enolate-based methodology is suitable for access to propionate syn-aldol motifs with high levels of stereocontrol. The reactive lithium enolate species is generated by direct treatment of a camphor-based chiral ethyl ketone with butyllithium, and is subsequently submitted to aldolization with a broad variety of aldehydes. The product aldols are obtained in uniformly high yields and high d.r. values (ranging from 91:9 to >98:2) irrespective of the aliphatic (both linear and branched chain), $\alpha, \beta$-unsaturated, aromatic, or hetero-aromatic nature of the aldehyde employed. The crystallinity of most of the obtained adducts offers an easy access to almost $100 \%$ isomerically pure products upon a single recrystallisation. The auxiliary (1R)$(+)$-camphor can be removed easily from the adducts for reuse, thereby producing the corresponding syn propionate aldols. This technology is implemented in the synthesis of a key subunit of the multi-drug resistance reversing agent hapalosin.
\end{abstract}

Keywords: Lithium enolates, aldol reaction, asymmetric synthesis, hapalosin, butyllithium

\section{Introduction}

The significance of the aldol addition reaction ${ }^{1}$ as one of the prominent carbon-carbon bond forming processes continues to expand, ${ }^{2}$ in part because of its suitability as a means of accessing structurally and stereochemically complex backbones of many natural products. This prevalence has gained new impetus with the advent, and incipient development, of catalytic direct aldol 
addition reactions during the last couple of years. ${ }^{3,4}$ This methodology is particularly suitable when the enolizable carbonyl substrates involved are methyl ketones (acetone, acetophenones), hydroxymethyl ketones (hydroxyacetone), alkoxyaldehydes, and glycine equivalents. However, more limited results are generally obtained when propionate equivalents are employed. ${ }^{5,6}$ In this context, besides the Mukaiyama aldol approach, the boron aldol reaction represents the most powerful platform for building up propionate motifs and its generality, versatility and selectivity is nowadays well documented. ${ }^{7}$ Highly stereoselective propionate aldol reactions involving other metal enolates such as those of $\mathrm{Ti}, \mathrm{Zr}$ and $\mathrm{Sn}$ have also been reported. Significantly, the most primary of the metal-based aldol reactions, namely that involving lithium enolates, ${ }^{8}$ has found no general application due to the low selectivities. The speculative origin of the low level of asymmetric induction usually observed in lithium enolate-mediated aldol reactions is twopronged. On one hand, the bond length-to-atomic radius ratio for the Li-O bond is relatively large (for example, bond lengths: Li-O 1.92-2.00 $\AA$; B-O 1.36-1.47 $\AA$ ) and on the other hand, the Li metal center usually lacks resident bulky ligands. ${ }^{9}$ Research from these laboratories has documented the efficiency of the lithium enolate $\mathbf{1}$ in successfully addressing the problem of insufficient stereoselectivity often encountered in acetate aldol additions and related reactions. ${ }^{10,11}$ We reasoned that two major design elements of this model, namelly the sterically encumbered camphor skeleton and the strength of the 1,4-metal chelation in the $\alpha^{\prime}$-silyloxy ketone enolate, could serve to produce a less flexible and more biased reactive enolate. In this article we present the implementation of this idea with the development of a highly stereoselective propionate aldol protocol based on camphor-derived lithium enolate 2.

\section{Results and Discussion}

Enantiomerically pure ethyl ketone 5, the precursor needed for enolate 2, can be prepared conveniently in multi-gram quantities from the cheap (1R)-(+)-camphor following two alternative paths, Scheme 1. Compound 5 is obtained in $90 \%$ yield by simple methylation of $\mathbf{4}^{12}$ or alternatively through a sequence involving cyanation of camphor and chromatographic purification of the endo adduct $\mathbf{6}^{\mathbf{1 3}}$ (90\%); addition of ethyllithium to 6; mild acid hydrolysis; and re-silylation ( $70 \%$ yield after purification).

Survey experiments revealed that enolization of 5 can be achieved conveniently by simply using $\mathrm{n}$-BuLi at temperatures below $-30^{\circ} \mathrm{C}$. Under these conditions, Li-enolate solutions were cleanly obtained free of any amine by-product, in contrast to most traditional enolization protocols based on lithium amide bases which inherently rend the corresponding amine byproduct. This realization indicates that the carbonyl group in ketone $\mathbf{5}$ is sterically protected against nucleophilic alkylation in a very efficient manner. To the best of our knowledge, to date only achiral appendages have been successfully used to sterically protect ketone ${ }^{14}$ and carboxylic acid $^{15}$ carbonyls against an eventual nucleophilic attack by an alkyllithium reagent. 


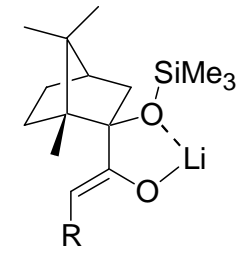

$1 \mathrm{R}: \mathrm{H}$

2 R: Me

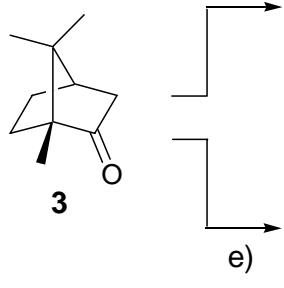

e)
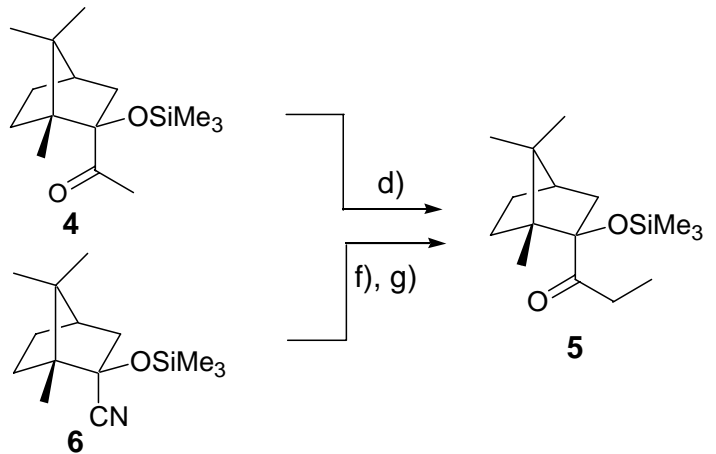

Scheme 1. Preparation of reagent 5. (a) $\mathrm{C}_{2} \mathrm{HLi}$, THF, $-78^{\circ} \mathrm{C} \rightarrow$ r.t., $90 \%$. (b) $\mathrm{HgO}, \mathrm{H}_{2} \mathrm{SO}_{4}$, $\mathrm{Me}_{2} \mathrm{CO}$, reflux, $85 \%$. (c) $\mathrm{KH}, \mathrm{ClSiMe}_{3}$, THF, $0^{\circ} \mathrm{C} \rightarrow$ r.t., 1 h, quantitative. (d) LDA (1.3 equiv.), $\mathrm{THF},-78^{\circ} \mathrm{C}$, $2 \mathrm{~h}$ then $\mathrm{MeI}\left(1.3\right.$ equiv.), $-30^{\circ} \mathrm{C}, 1.5 \mathrm{~h}, 90 \%$. (e) $\mathrm{CNSiMe}_{3}, \mathrm{LiOMe}, \mathrm{THF}$, r.t., $90 \%$. (f) $\mathrm{EtLi}, \mathrm{Et}_{2} \mathrm{O}, 0^{\circ} \mathrm{C}, 2 \mathrm{~h}$ then $\mathrm{AcOH}, 78 \%$. (e) As in c), r.t., 30min, 95\%.

Concurrent with the above observations, it was found that the distribution of isomeric aldol products is strongly solvent- and temperature-dependent. A systematic study of the d.e. values as a function of the temperature ${ }^{16}$ using four meaningful solvents was undertaken for the model reaction between the Li-enolate of 5 and benzaldehyde. From the experimental data collected, ${ }^{17}$ Figure 1, a divergence is observed at temperatures bellow $-30^{\circ} \mathrm{C}$, with 1,2-dimethoxyethane (DME) and THF being superior solvents in comparison with diethyl ether and hexane. Accordingly, optimized reaction conditions for further exploration were set using DME solvent at low temperatures $\left(-78^{\circ} \mathrm{C}\right)$.

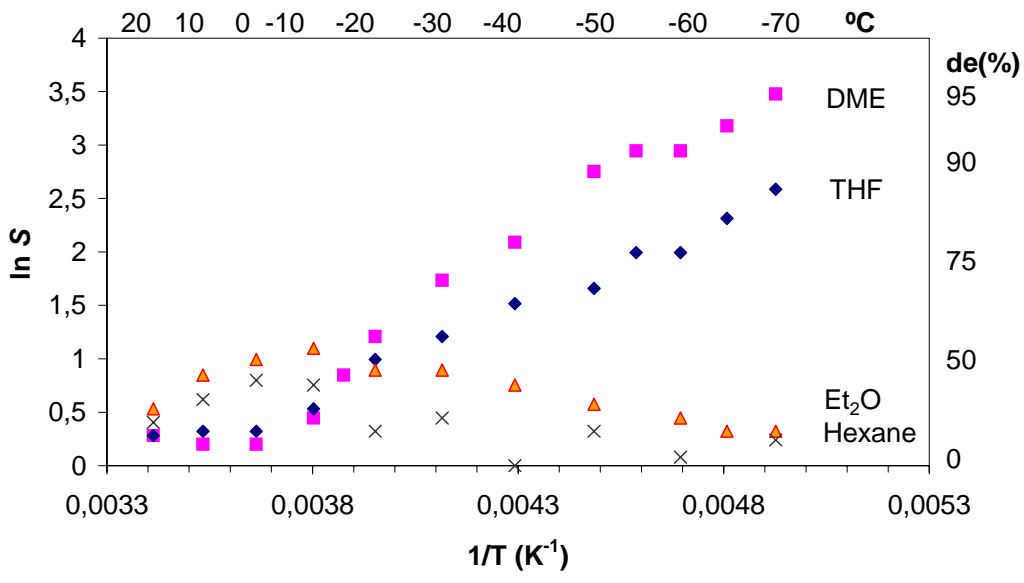

Figure 1. Eyring plots for the diastereoisomeric excess obtained in the aldol reaction between the lithium enolate of 5 and benzaldehyde in DME, THF, $\mathrm{Et}_{2} \mathrm{O}$, and hexane. The experimental $S$ is calculated as the measured ratio 7/8 ( ${ }^{13} \mathrm{C}$ NMR). See Ref. 16 for pertinent information. 

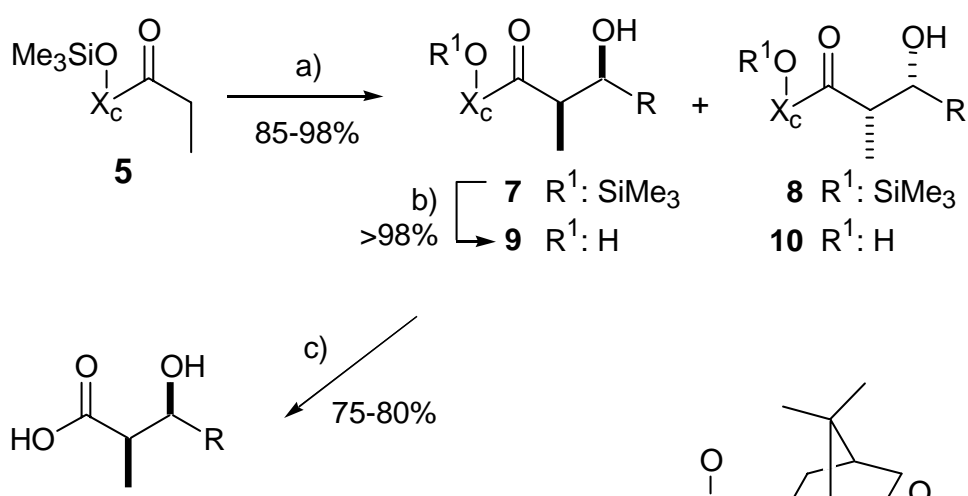

$11 \mathrm{R}: \mathrm{i}^{\mathrm{Pr}}$

$12 \mathrm{R}: \mathrm{Ph}$

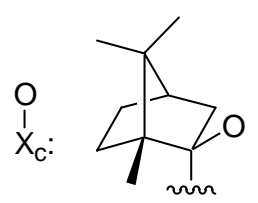

Scheme 2. Asymmetric "propionate" aldol reactions based on the lithium enolate of 5. " (a) nBuLi (1.2 equiv., 1.6M in hexane), DME, $-50^{\circ} \mathrm{C}, 30-45 \mathrm{~min}$ then $\mathrm{RCHO}$ (1.5-2 equiv.), DME, $-78^{\circ} \mathrm{C}, 45-60 \mathrm{~min}$. (b) $\mathrm{HF} / \mathrm{MeOH}$, r.t., $15 \mathrm{~min}$. (c) $\left(\mathrm{NH}_{4}\right)_{2} \mathrm{Ce}\left(\mathrm{NO}_{3}\right)_{6}$ (3 equiv.), $\mathrm{CH}_{3} \mathrm{CN}-\mathrm{H}_{2} \mathrm{O}, 0^{\circ} \mathrm{C}$, $1 \mathrm{~h}$.

On the other hand, while the substitution of the trimethylsilyl group in ketone 5 by triethylsilyl and tert-butyldimethylsilyl does not affect the stereochemical outcome of the reaction, Table 1, the triisopropylsilyloxy ketone $\mathbf{1 5}$ leads to a non-selective aldol reaction. ${ }^{18}$

Table 1. Effect of the trialkylsilyl group on the propionate aldol reaction with propanal ${ }^{\mathrm{a}}$

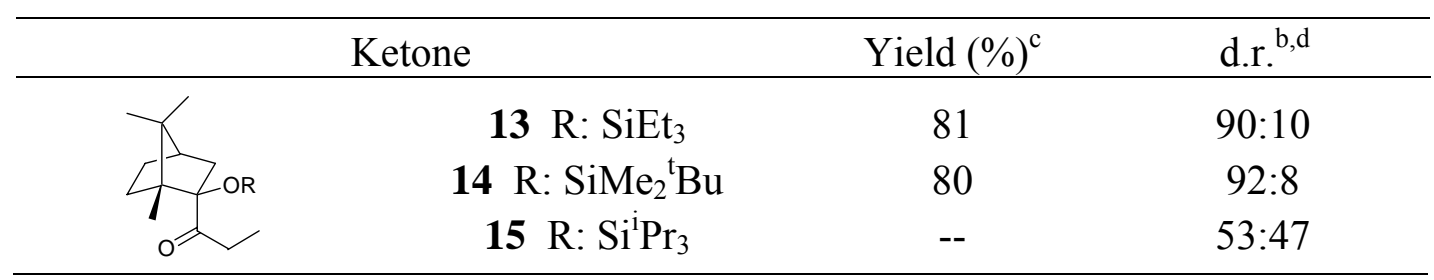

${ }^{a}$ Reactions conducted at $-78^{\circ} \mathrm{C}$ on a $1 \mathrm{mmol}$ scale by adding the aldehyde to the corresponding enolate. The enolate was generated in DME at $-50^{\circ} \mathrm{C}$ with $\mathrm{n}-\mathrm{BuLi}(2.5 \mathrm{M}$ in hexane) during 45 min. ${ }^{b}$ Determined by ${ }^{1} \mathrm{H}$ NMR $(500 \mathrm{MHz})$. ${ }^{\mathrm{c}}$ Isolated yield of the major isomer by column chromatography. ${ }^{\mathrm{d}}$ Configuration of the minor isomer not established.

The scope of this reaction system under the optimized conditions was then explored using an ample variety of aldehydes, Table 2 . Thus, aliphatic, $\alpha, \beta$-unsaturated, aromatic and heterocyclic aldehydes all gave the desired aldol product with high yields and in diastereoselectivities within the 91:9 to $>98: 2$ range. ${ }^{19}$ This broad tolerance is comparable with that recognized for the well-established boron-aldol methodologies. A practical aspect of the present reaction model is that most aldol products $\mathbf{7}$ or $\mathbf{9}$ are crystalline solids, and analytically pure samples of $\geq 99 \%$ d.e. can be isolated by direct crystallization from the crude reaction mixture. 
Table 2. Lithium aldol reactions of 5 with representative aldehydes ${ }^{\mathrm{a}}$

\begin{tabular}{|c|c|c|c|c|c|c|c|c|c|}
\hline \multirow[b]{2}{*}{ Entry } & \multirow[b]{2}{*}{ Aldehyde } & \multicolumn{3}{|c|}{ Ratio $^{\mathrm{b}}$ Compound 7} & \multirow[b]{2}{*}{ Entry } & \multirow[b]{2}{*}{ Aldehyde } & \multirow{2}{*}{$\begin{array}{c}\text { Ratio }^{\mathrm{b}} \\
\mathbf{7 / 8}\end{array}$} & \multicolumn{2}{|c|}{ Compound 7} \\
\hline & & $7 / 8$ & Yield & M.p. & & & & Yield $^{c}$ & M.p. \\
\hline $\mathrm{a}$ & $\mathrm{CH}_{3} \mathrm{CHO}$ & $92: 8$ & 85 & $104-105^{\mathrm{d}}$ & $\mathrm{k}$ & & $98: 2$ & 88 & $155-156$ \\
\hline $\mathrm{b}$ & $\mathrm{CH}_{3} \mathrm{CH}_{2} \mathrm{CHO}$ & $94: 6$ & 89 & Oil & 1 & & $98: 2$ & 85 & $137: 139$ \\
\hline $\mathrm{c}$ & $\mathrm{CH}_{3}\left(\mathrm{CH}_{2}\right)_{3} \mathrm{CHO}$ & $91: 9$ & 82 & $99-101^{\mathrm{d}}$ & $\mathrm{m}$ & & $93: 7$ & 90 & $116-117$ \\
\hline d & $\mathrm{PhCH}_{2} \mathrm{CH}_{2} \mathrm{CHO}$ & $94: 6$ & 86 & $99-100^{d}$ & $\mathrm{n}$ & & $>98: 2$ & 98 & $117-119$ \\
\hline e & $\mathrm{CH}_{3}\left(\mathrm{CH}_{2}\right)_{5} \mathrm{CHO}$ & $94: 6$ & 84 & Oil & o & & $98: 2$ & 93 & $151-152$ \\
\hline $\mathrm{f}$ & $\begin{array}{c}\left(\mathrm{CH}_{3}\right) \\
{ }_{2} \mathrm{CHCH}_{2} \mathrm{CHO}\end{array}$ & 95:5 & 84 & Oil & $\mathrm{p}$ & & $97: 3$ & 93 & $160-161$ \\
\hline $\mathrm{g}$ & $\left(\mathrm{CH}_{3}\right)_{2} \mathrm{CHCHO}$ & $97: 3$ & 87 & $62-63$ & q & & $95: 5$ & 90 & $137-139$ \\
\hline $\mathrm{h}$ & $\mathrm{CHO}$ & $97: 3$ & 90 & $122-124$ & $\mathrm{r}$ & & $97: 3$ & 92 & $158-160$ \\
\hline $\mathrm{i}$ & & $95: 5$ & 88 & $49-50$ & $\mathrm{~s}$ & & $96: 4$ & 89 & $145-146$ \\
\hline $\mathrm{j}$ & $=\mathrm{CHO}$ & $96: 4$ & 94 & $131-133$ & $\mathrm{t}$ & & $>98: 2$ & 90 & $151-153$ \\
\hline
\end{tabular}

${ }^{\text {a }}$ Reactions conducted on a $5 \mathrm{mmol}$ scale in 1,2-dimethoxyethane (DME) at $-78^{\circ} \mathrm{C}$ for $45-60$ min; ratio ketone:aldehyde 1:1.5-2. ${ }^{\mathrm{b}}$ Determined by ${ }^{1} \mathrm{H}$ NMR $(500 \mathrm{MHz})$ and/or ${ }^{13} \mathrm{C} \mathrm{NMR}$ (75MHz). ${ }^{c}$ Yields of 7 after purification of the crude product by column chromatography and/or crystallization from hexane. ${ }^{\mathrm{d}}$ Melting point of the desilylated compound $\mathbf{9}$.

The excellent diastereoselectivity observed in these reactions is also of particular interest in that it provides a clean access to propionate aldols upon auxiliary cleavage. For example, when adducts $9 \mathbf{g}$ and $9 \mathbf{k}$ were subjected to oxidative cleavage with ammonium cerium nitrate (CAN), the carboxylic acids $\mathbf{1 1}$ and 12 were formed in $75 \%$ and $80 \%$ yields, respectively. The observed optical rotations of these $\beta$-hydroxy carboxylic acids were then compared with published values. ${ }^{20}$ In addition, a single crystal X-ray structure analysis of compounds 8d, 7k and $\mathbf{8 k}$ corroborated the assigned configurations of the adducts. ${ }^{21}$ Importantly, (1R)-(+)camphor, the starting source of chiral information, which is formed during treatment with CAN, is easily recovered from the reaction mixture in each case almost quantitatively and without loss of optical integrity. ${ }^{22}$. 

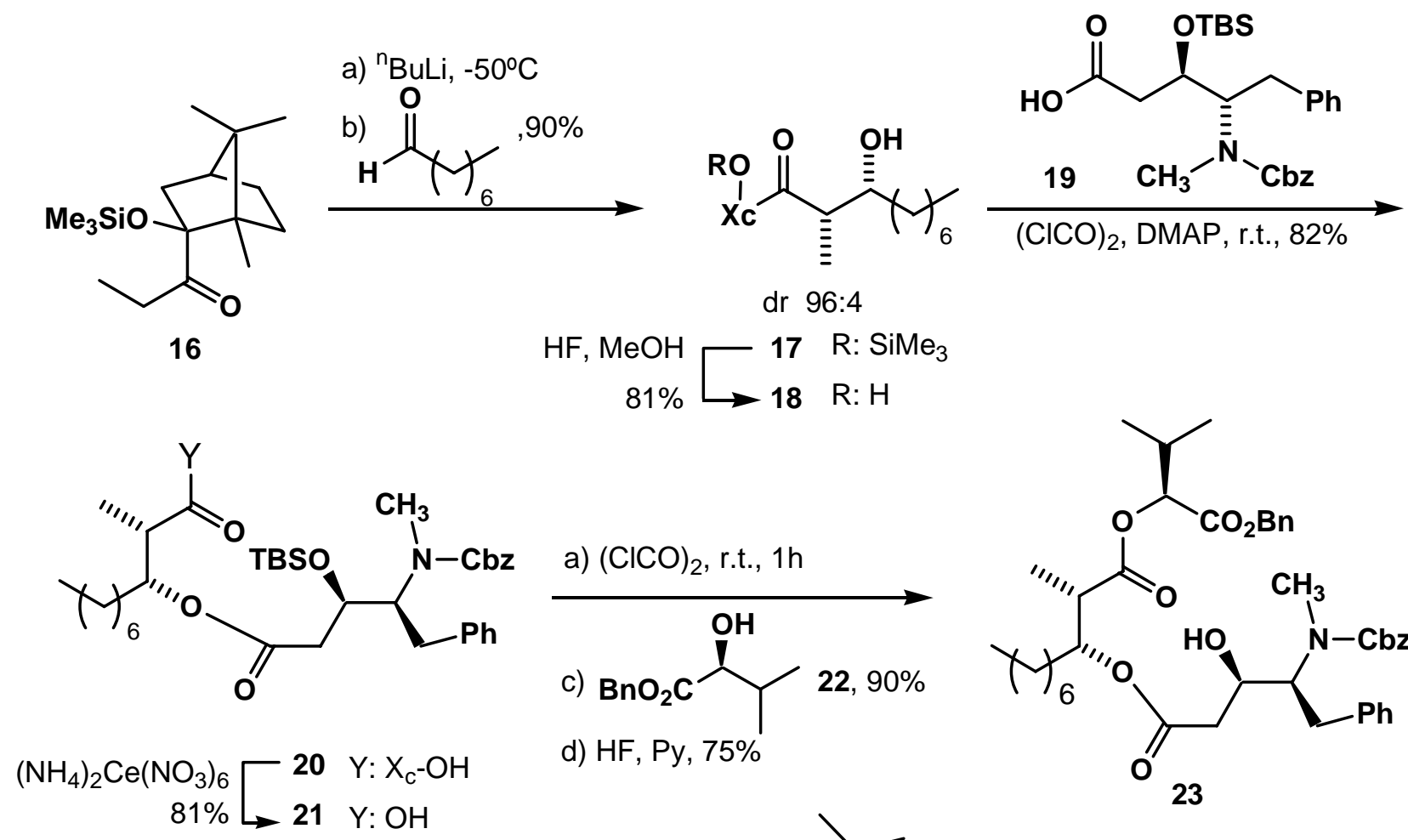

a) $(\mathrm{CICO})_{2}$, r.t., $1 \mathrm{~h}$

a) $\mathrm{H}_{2}, \mathrm{Pd} / \mathrm{C}, \mathrm{CF}_{3} \mathrm{CO}_{2} \mathrm{H}, 80 \%$

b) Diphenylphosphoryl azide

EtN'Pr${ }^{\mathrm{i}}, \mathrm{DMF}$

(1 mmol/L), $25 \%$
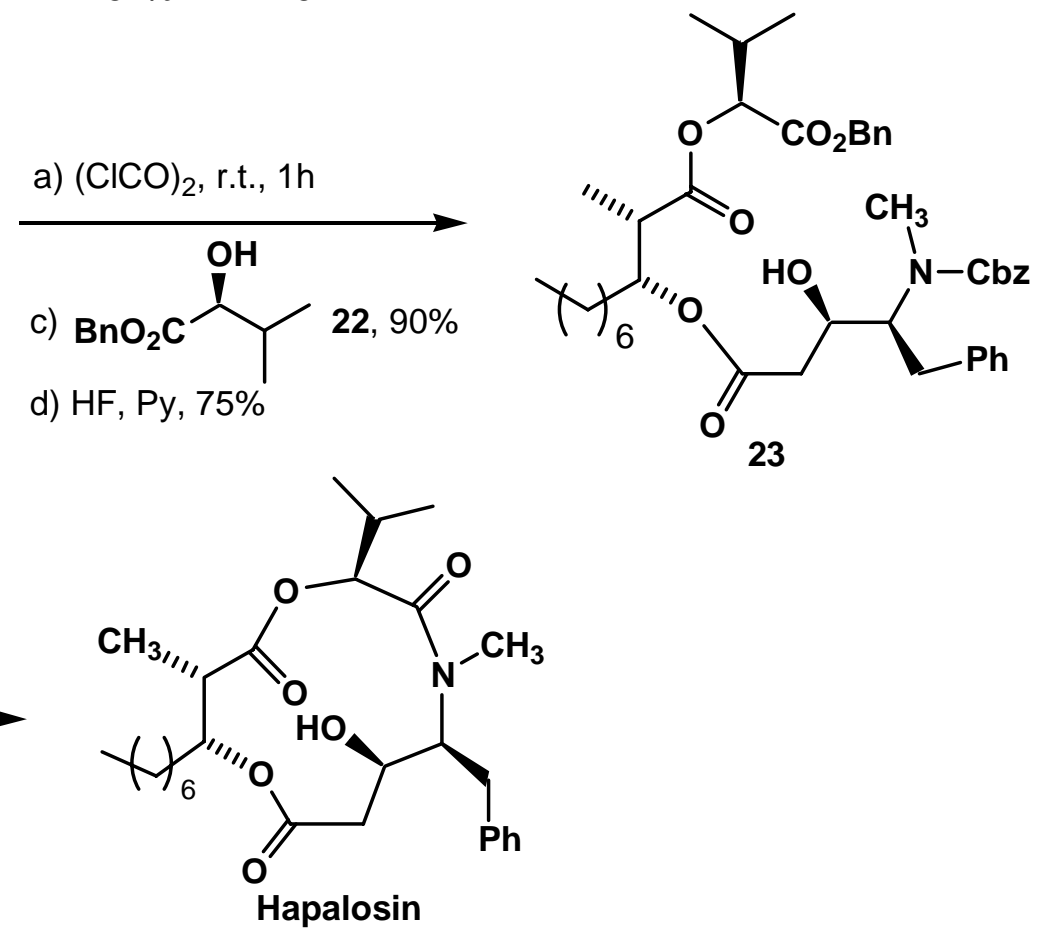

Scheme 3. Application of the new lithium-based propionate aldol methodology to the synthesis of the multidrug resistance reversing agent hapalosin.

Another feature of the present model is shown in the synthesis of the multidrug resistance reversing agent hapalosin, ${ }^{23}$ Scheme 3 , wherein the camphor moiety in the ethyl ketone $\mathbf{1 6}$ plays a dual role. On the one hand, it controls the stereochemistry of the key aldol bond construction step to provide 17 in $90 \%$ yield as the major product, while, on the other hand, it allows for an efficient protection of the carboxylic acid group, masked in the form of an acyloin moiety. Thus, compound 17 after desilylation and further coupling of the resulting 18 with the acid chloride of $19^{23 \mathrm{~d}}$ furnished the ester segment 20 in $82 \%$ yield. This adduct, upon oxidative treatment with CAN, gave 21, ready for subsequent coupling at the carboxyl terminus. Completion of the synthesis of the hapalosin was accomplished as shown in Scheme 3 from 23, which is readily available by coupling 22 with $\mathbf{2 1}$, by final macrolactamization according to Maier's protocol. ${ }^{24}$ 
In summary, a Li-mediated diastereoselective aldol addition approach to syn propionate aldol motifs is presented, which helps to close the gap in the asymmetric lithium aldol methodology. In this model, the chiral controller of the process, (1R)- $(+)$-camphor and/or its enantiomer, is cheap, almost fully recoverable, and can be reused without loss of efficiency. Of practical importance, amine-free lithium enolate solutions are cleanly obtained by direct treatment of the ethyl ketone reagent with n-BuLi as base.

\section{Experimental Section}

General Procedures. All reactions were carried out under an atmosphere of nitrogen in oven or flame-dried glassware with magnetic stirring. Solvents were distilled prior to use. Tetrahydrofuran (THF), Dimethoxyethane (DME) and diethyl ether were distilled from sodium metal/benzophenone ketyl. Hexane was distilled from sodium. Acetonitrile $\left(\mathrm{CH}_{3} \mathrm{CN}\right)$ and dichloromethane $\left(\mathrm{CH}_{2} \mathrm{Cl}_{2}\right)$ were distilled from calcium hydride. Purification of reaction products was carried out by flash chromatography using silicagel 60 (230-400 mesh, from Merck 60F $\mathrm{PF}_{254}$ ). Analytical thin layer chromatography was performed on $0.25 \mathrm{~mm}$ silica gel $60-\mathrm{F}$ plates. Visualization was accomplished with UV light and phosphomolybdic acid-ammonium cerium (IV) nitrate-sulfuric acid-water reagent, followed by heating. Melting points were measured with a Büchi SMP-20 melting point apparatus and are uncorrected. Infrared spectra were recorded on a Shimadzu IR-435 and a Nicolet Avatar 360-FT-IR spectrophotometers. ${ }^{1} \mathrm{H}$ NMR and ${ }^{13} \mathrm{C}$ NMR spectra were recorded on a Bruker Avance DPX300, a Bruker Ultrashield ${ }^{\mathrm{TM}} 500$ and a Varian Gemini 200 spectrometers and are reported as $\delta$ values (ppm) relative to residual $\mathrm{CHCl}_{3} \delta \mathrm{H}(7.26$ ppm) and $\mathrm{CDCl}_{3} \delta \mathrm{C}(77.00 \mathrm{ppm})$ as internal standards, respectively. Combustion analyses were performed on a Leco CHNS-932 elemental analyzer. Optical rotations were measured at 25 $\pm 0.2{ }^{\circ} \mathrm{C}$ on a Jasco Polarimeter DIP-370 and a Perkin-Elmer apparatus in methylene chloride unless otherwise stated.

(1R)-2-endo-Acetyl-2-exo-trimethylsilyloxy-1,7,7-trimethylbicyclo[2.2.1]heptane (4). Method A: (Procedure reported in ref. 10c) An oven-dried, 2 1, three-necked round-bottomed flask, equipped with a thermometer and a magnetic stirrer bar was flushed with nitrogen, charged with THF $(500 \mathrm{ml})$ and cooled to $-78{ }^{\circ} \mathrm{C}$. Butyllithium $(2.5 \mathrm{M}$ in hexane, $150 \mathrm{ml}, 375 \mathrm{mmol})$ was added using a syringe and dry acetylene was blown over the yellow solution held below $-70{ }^{\circ} \mathrm{C}$ for 45 minutes. Then neat R-(+)-camphor (45.69 g, $300 \mathrm{mmol}$ ) was added over the clear solution of lithium acetylide at the same temperature. After the addition, the cold bath was removed and the mixture was stirred overnight at room temperature. The flask was opened to the atmosphere and $1 \mathrm{M} \mathrm{HCl}(150 \mathrm{ml})$ was added slowly. The quenched reaction was stirred for 1 hour and then the solvent was removed at reduced pressure. $\mathrm{CH}_{2} \mathrm{Cl}_{2}(400 \mathrm{ml})$ was added and the mixture was transferred to a separatory funnel. The aqueous layer was separated and the organic layer was washed with $1 \mathrm{M} \mathrm{HCl}$. The combined aqueous layers were extracted with $\mathrm{CH}_{2} \mathrm{Cl}_{2}$ and the 
combined organic extracts were washed with a saturated solution of $\mathrm{NaHCO}_{3}$, dried over $\mathrm{MgSO}_{4}$, filtered and the solvent was removed under reduced pressure to give a mixture of ethynyl carbinols, endo:exo 97:3, as a dark oil. This crude material was dissolved in acetone $(300 \mathrm{~mL})$ and added dropwise over a period of 1.5 hours to a warmed $\left(60^{\circ} \mathrm{C}\right)$ mixture prepared previously as follows: In a three-necked round-bottomed flask, equipped with a reflux condenser, a magnetic stirrer bar and a dropping funnel, red mercuric oxide $(4.0 \mathrm{~g})$ was dissolved in a solution of concentrated sulfuric acid $(3.6 \mathrm{ml})$, water $(150 \mathrm{ml})$ and acetone $(700 \mathrm{ml})$. The resulting reaction mixture was stirred at $60{ }^{\circ} \mathrm{C}$ for an additional 15 minutes and allowed to cool. A saturated aqueous solution of $\mathrm{NaHCO}_{3}(250 \mathrm{ml})$ was added to the reaction mixture, the solvent was removed under reduced pressure and $\mathrm{CH}_{2} \mathrm{Cl}_{2}(350 \mathrm{ml})$ was added. The aqueous layer was separated, and the organic layer was washed with saturated solution of $\mathrm{NaHCO}_{3}$. The combined aqueous layers were extracted with $\mathrm{CH}_{2} \mathrm{Cl}_{2}$ and the organic extracts were combined, dried over $\mathrm{MgSO}_{4}$ and filtered. The solvent was removed under reduced pressure and the solid crude product was purified by crystallization from hexane. Yield: $52.8 \mathrm{~g}, 90 \%, \mathrm{mp} 94-95^{\circ} \mathrm{C} ;[\alpha]_{\mathrm{D}}{ }^{25}=-$ $65.6\left(c=1.0, \mathrm{CH}_{2} \mathrm{Cl}_{2}\right)$; IR ( $\left.\mathrm{KBr}\right)$ : v 3421, $1690 \mathrm{~cm}^{-1} ;{ }^{1} \mathrm{H} \mathrm{NMR}\left(\mathrm{CDCl}_{3}, \delta\right) 0.83$ and $0.92(\mathrm{~s}, 3 \mathrm{H})$, 1.03-0.95 (m, 1H), $1.08(\mathrm{~s}, 3 \mathrm{H}), 1.27-1.15(\mathrm{~m}, 1 \mathrm{H}), 1.49-1.34(\mathrm{~m}, 1 \mathrm{H}), 1.74-1.65(\mathrm{~m}, 1 \mathrm{H}), 1.90-$ $1.81(\mathrm{~m}, 2 \mathrm{H}), 2.25(\mathrm{~s}, 3 \mathrm{H}), 2.14-2.29(\mathrm{~m}, 1 \mathrm{H}), 2.65(\mathrm{~s}, 1 \mathrm{H}) ;{ }^{13} \mathrm{C} \mathrm{NMR}(\mathrm{CDCl} 3, \delta)$ 10.5, 20.3, 20.8, 26.4, 27.6, 30.1 , 40.9, 45.0, 50.3, 52.1, 87.4, 211.8; Anal. Calcd for $\mathrm{C}_{12} \mathrm{H}_{20} \mathrm{O} 2$ (196.32): C, 73.41; H, 10.29. Found: C, 73.06; H, 10.32.

A solution of this compound $(50 \mathrm{mmol}, 9.8 \mathrm{~g})$ in dry THF $(50 \mathrm{~mL})$ was added dropwise to a mixture of $\mathrm{KH}$ (2.5 mmol, 35\% dispersion in mineral oil, previously washed with dry hexane) and THF $(100 \mathrm{~mL})$ at $0^{\circ} \mathrm{C}$. The resulting mixture was stirred at the same temperature for 10 minutes, trimethylchlorosilane $(100 \mathrm{mmol}, 12.0 \mathrm{~mL})$ was added, and the mixture stirred at room temperature for an additional 1 hour. Water $(50 \mathrm{~mL})$ was then slowly added at $0^{\circ} \mathrm{C}$ and, after completion of the addition, the layers were separated and the aqueous layer was extracted with $\mathrm{CH}_{2} \mathrm{Cl}_{2}(3 \times 50 \mathrm{~mL})$. The combined organic layer was washed with water $(30 \mathrm{~mL})$, dried over $\mathrm{MgSO}_{4}$, filtered, and the solvent evaporated under reduced pressure. Yield: $2.68 \mathrm{~g}, 100 \%, \mathrm{mp}$ $38^{\circ} \mathrm{C} ;[\alpha]_{\mathrm{D}}{ }^{25}=-24.9\left(c=1.0, \mathrm{CH}_{2} \mathrm{Cl}_{2}\right)$; IR $(\mathrm{KBr}): v 1708 \mathrm{~cm}^{-1} ;{ }^{1} \mathrm{H} \mathrm{NMR}\left(\mathrm{CDCl}_{3}, \delta\right) 0.06(\mathrm{~s}, 9 \mathrm{H})$, 0.76-0.08 (m, $1 \mathrm{H}), 0.80,0.98$ and $1.03(\mathrm{~s}, 3 \mathrm{H}), 1.11-1.05$ and $1.40-1.26(\mathrm{~m}, 1 \mathrm{H}), 1.57(\mathrm{~s}, 1 \mathrm{H})$, 1.77-1.69 (m, 2H), 2.15 (s, 3H), 2.51-2.45 (m, 1H); ${ }^{13} \mathrm{C} \mathrm{NMR}\left(\mathrm{CDCl}_{3}, \delta\right)$ 1.7, 11.4, 20.3, 21.0, 25.8, 26.9, 30.1, 39.7, 45.3, 50.9, 51.6, 90.7, 209.3; Anal. Calcd for $\mathrm{C}_{15} \mathrm{H}_{28} \mathrm{O}_{2} \mathrm{Si}$ (268.52): C, 67.09; H, 10.53. Found: C, 66.75; H, 10.56 .

Method B: ${ }^{25}$ To a solution of lithium acetylide, ethylenediamine complex (Aldrich) (11.96 g, $130 \mathrm{mmol})$ in THF $(250 \mathrm{~mL})$ at $0{ }^{\circ} \mathrm{C}$ was added $(1 \mathrm{R})-(+)$-camphor $(15.22 \mathrm{~g}, 100 \mathrm{mmol})$ and the reaction mixture was warmed to $40^{\circ} \mathrm{C}$ and stirred for overnight. The resulting solution was cooled in an ice-bath and quenched by the slow addition of water $(160 \mathrm{~mL})$. The organic layer was separated and the aqueous layer was extracted with $\mathrm{CH}_{2} \mathrm{Cl}_{2}(2 \mathrm{x} 100 \mathrm{~mL})$. The combined organic layers were washed with brine, dried over $\mathrm{MgSO}_{4}$, filtered and concentrated under reduced pressure to give a mixture of ethynyl carbinols, endo:exo 97:3, as a dark oil. Hydration and subsequent silylation of this material was carried out as in Method A. 
(1R)-2-exo-Trimethylsilyloxy-1,7,7-trimethylbicyclo[2.2.1]heptane-2-carbonitrile $\quad(6){ }^{26} \mathrm{~A}$ solution of lithium methoxide $(0.23 \mathrm{~g}, 5.96 \mathrm{mmol})$ and trimethylsilyl cyanide $(16 \mathrm{~mL}, 120 \mathrm{mmol})$ in THF $(200 \mathrm{~mL})$ was stirred at room temperature for 10 minutes and then $(\mathrm{R})-(+)$-camphor (15.2 $\mathrm{g}, 100 \mathrm{mmol}$ ) was added. The mixture was stirred at room temperature for 4 hours. Then $\mathrm{CH}_{2} \mathrm{Cl}_{2}(100 \mathrm{~mL})$ was added and the mixture was washed with a saturated aqueous solution of $\mathrm{Na}_{2} \mathrm{CO}_{3}(2 \times 50 \mathrm{~mL})$. The organic extract was dried over $\mathrm{MgSO}_{4}$, filtered, and the solvent was evaporated to afford the endo-exo mixture in a ratio of 96:4. Purification was effected by flash column chromatography using 1:30 EtOAc-hexane mixture as the eluant, which yielded the endo isomer. Yield: $22.6 \mathrm{~g}, 90 \%$. Data for endo-6: b.p. $147^{\circ} \mathrm{C} / 9$ torr; $[\alpha]_{\mathrm{D}}{ }^{25}=-31.0\left(c=1.2, \mathrm{CH}_{2} \mathrm{Cl}_{2}\right)$; IR (KBr): v $2230 \mathrm{~cm}^{-1} ;{ }^{1} \mathrm{H}$ NMR (200 MHz, $\mathrm{CDCl}_{3}, 20{ }^{\circ} \mathrm{C}, \delta$ 2.23-2.12 (m, 1H, HCH), 2.05-1.99 (m, 1H, $\mathrm{HCH}), 1.89-1.49\left(\mathrm{~m}, 4 \mathrm{H}, \mathrm{CH}_{2}, \mathrm{CH}_{2}\right), 1.23-1.01(\mathrm{~m}, 1 \mathrm{H}, \mathrm{HCH}), 0.96,0.92$ and 0.85 (s, $\left.3 \mathrm{H}, \mathrm{CH}_{3} \mathrm{C}\right), 0.20\left(\mathrm{~s}, 9 \mathrm{H},\left(\mathrm{CH}_{3}\right)_{3} \mathrm{Si}\right) ;{ }^{13} \mathrm{C} \mathrm{NMR}\left(50 \mathrm{MHz}, \mathrm{CDCl}_{3}, 20{ }^{\circ} \mathrm{C}, \delta\right) 1.1,10.6,20.5,21.1$, 26.5, 31.7, 45.1, 47.8, 48.6, 54.1, 78.5, 121.9.

(1R)-2-endo-Propanoyl-2-exo-trimethylsilyloxy-1,7,7-trimethylbicyclo[2.2.1]heptane

(5). Method A: A solution of diisopropylamine $(2.04 \mathrm{ml}, 14.53 \mathrm{mmol})$ in dry THF $(28 \mathrm{ml})$ was cooled to $-78{ }^{\circ} \mathrm{C}$ under a nitrogen atmosphere and n-butyllithium $(2.5 \mathrm{M}$ in hexane, $5.8 \mathrm{ml}$, $14.53 \mathrm{mmol}$ ) was added dropwise. After 30 minutes of stirring at the same temperature, a solution of methyl ketone $4(3.0 \mathrm{~g}, 11.18 \mathrm{mmol})$ in dry THF $(28 \mathrm{ml})$ was added dropwise and stirring was continued at $-78^{\circ} \mathrm{C}$ for $2 \mathrm{~h}$. Then methyl iodide $(2.21 \mathrm{~mL}, 14.53 \mathrm{mmol})$ was added at the same temperature and the mixture was stirred at $-30^{\circ} \mathrm{C}$ for $1.5 \mathrm{~h}$. The reaction was quenched at $-30{ }^{\circ} \mathrm{C}$ with $60 \mathrm{~mL}$ of $1 \mathrm{~N} \mathrm{HCl}$, and the mixture was allowed to reach room temperature. The aqueous phase was extracted with hexane $(3 \times 60 \mathrm{~mL})$ and the combined organic layers were dried over $\mathrm{MgSO}_{4}$ and evaporated under reduced pressure to give the title compound 5. Yield $2.84 \mathrm{~g}(90 \%)$ b.p. $100^{\circ} \mathrm{C} / 0.05$ torr; $[\alpha]_{\mathrm{D}}{ }^{25}=-29.2\left(c=1.2, \mathrm{CH}_{2} \mathrm{Cl}_{2}\right)$; IR (film): v $1711 \mathrm{~cm}^{-1} ;{ }^{1} \mathrm{H} \mathrm{NMR}\left(200 \mathrm{MHz}, \mathrm{CDCl}_{3}, 20{ }^{\circ} \mathrm{C}, \delta\right) 0.07\left(\mathrm{~s}, 9 \mathrm{H},\left(\mathrm{CH}_{3}\right)_{3} \mathrm{Si}\right), 0.82,1.00$ and 1.05 $\left(\mathrm{s}, 3 \mathrm{H}, \mathrm{CH}_{3} \mathrm{C}\right), 1.06\left(\mathrm{t}, J=7.3 \mathrm{~Hz}, 3 \mathrm{H}, \mathrm{CH}_{3} \mathrm{CH}_{2}\right), 1.40-1.12\left(\mathrm{~m}, 2 \mathrm{H}, \mathrm{CH}_{2}\right), 1.81-1.49(\mathrm{~m}, 3 \mathrm{H}$, $\left.\mathrm{CH}_{2}, \mathrm{CH}\right), 2.31\left(\mathrm{dq}, J=7.3 \mathrm{~Hz}, J^{\prime}=17.9 \mathrm{~Hz}, 1 \mathrm{H}, \mathrm{CHCH}_{3}\right), 2.58-2.52$ (m, 1H, HCH), 2.79 (dq, $J$ $\left.=7.3 \mathrm{~Hz}, J^{\prime}=7.3 \mathrm{~Hz}, J^{\prime}{ }^{\prime}=17.9 \mathrm{~Hz}\right) ;{ }^{13} \mathrm{C} \mathrm{NMR}\left(50 \mathrm{MHz}, \mathrm{CDCl}_{3}, 20{ }^{\circ} \mathrm{C}, \delta\right) 1.7,8.2,11.3,20.4$, 21.0, 25.8, 30.1, 31.4, 40.1, 45.2, 50.8, 51.6, 90.6, 212.0.

Method B: To a solution of $6(20.1 \mathrm{~g}, 80 \mathrm{mmol})$ in $\mathrm{Et}_{2} \mathrm{O}(240 \mathrm{~mL})$ at $0{ }^{\circ} \mathrm{C}$ was added a solution of EtLi in $\mathrm{Et}_{2} \mathrm{O}(1.4 \mathrm{M}, 114 \mathrm{~mL}, 160 \mathrm{mmol})$ and the mixture was stirred at the same temperature for 2 hours. Then glacial acetic acid $(30 \mathrm{~mL})$ was added to the mixture and stirred for 1 hour at $0{ }^{\circ} \mathrm{C}$. A saturated aqueous solution of $\mathrm{NaHCO}_{3}(100 \mathrm{~mL})$ was added and the resulting mixture was extracted with $\mathrm{CH}_{2} \mathrm{Cl}_{2}(2 \times 150 \mathrm{~mL})$. The combined organic layers were dried over $\mathrm{MgSO}_{4}$, filtered and the solvent was removed under reduced pressure. Purification was effected by flash column chromatography using 1:30 EtOAc-hexane mixture as the eluant, yielding endo-2-propanoylisoborneol. Yield: $13.1 \mathrm{~g}, 78 \%$, m.p. $45^{\circ} \mathrm{C} ;[\alpha]_{\mathrm{D}}{ }^{25}=-80.0(c=1.0$, $\mathrm{CH}_{2} \mathrm{Cl}_{2}$ ); IR (KBr): v 3541, $1694 \mathrm{~cm}^{-1} ;{ }^{1} \mathrm{H} \mathrm{NMR}\left(200 \mathrm{MHz}, \mathrm{CDCl}_{3}, 20{ }^{\circ} \mathrm{C}, \delta\right) 0.82$ and 0.91 (s, $3 \mathrm{H}, \mathrm{CH}_{3} \mathrm{C}$ ), $1.05\left(\mathrm{t}, J=7.2 \mathrm{~Hz}, 3 \mathrm{H}, \mathrm{CH}_{3} \mathrm{CH}_{2}\right), 1.08\left(\mathrm{~s}, 3 \mathrm{H}, \mathrm{CH}_{3} \mathrm{C}\right), 1.47-1.16,1.75-1.59$ and 1.92-1.77 (m, 2H, $\left.\mathrm{CH}_{2}\right), 2.24(\mathrm{~m}, 1 \mathrm{H}, \mathrm{HCH}), 2.45\left(\mathrm{dq}, J=7.2 \mathrm{~Hz}, J^{\prime}=17.8 \mathrm{~Hz}, 1 \mathrm{H}, \mathrm{HCHCH}_{3}\right)$, 
$2.71(\mathrm{~s}, 1 \mathrm{H}, \mathrm{OH}), 2.74\left(\mathrm{dq}, J=7.2 \mathrm{~Hz}, J^{\prime}=17.9 \mathrm{~Hz}, 1 \mathrm{H}, \mathrm{HCHCH}_{3}\right) ;{ }^{13} \mathrm{C} \mathrm{NMR}\left(50 \mathrm{MHz}, \mathrm{CDCl}_{3}\right.$, $\left.20{ }^{\circ} \mathrm{C}, \delta\right) 8.2$, 10.4, 20.4, 20.8, 26.6, 30.2, 32.8, 40.8, 45.0, 50.2, 52.3, 87.2, 214.8; Anal. Calcd for $\mathrm{C}_{13} \mathrm{H}_{22} \mathrm{O}_{2}$ : C 74.22, $\mathrm{H} 10.56$; found $\mathrm{C} 74.43, \mathrm{H} 10.51$. To a mixture of thus obtained endo-2propanoylisoborneol $(2.10 \mathrm{~g}, 10 \mathrm{mmol})$ and 3-trimethylsilyl-2-oxazolidinone TMSO (3.09 ml, $20 \mathrm{mmol}$ ) under a nitrogen atmosphere was added one drop of trifluoromethanesulfonic acid. The reaction mixture was stirred at room temperature for 30 minutes. Then $\mathrm{CH}_{2} \mathrm{Cl}_{2}(25 \mathrm{ml})$ was added and the resulting solution was washed with a saturated aqueous solution of $\mathrm{NaHCO}_{3}(2 \mathrm{x}$ $15 \mathrm{ml}$ ). The organic layer was dried over $\mathrm{MgSO}_{4}$, filtered and the solvent was removed under reduced pressure. Hexane $(15 \mathrm{ml})$ was added to the oily residue and the resulting white solid was filtered and washed with additional hexane $(15 \mathrm{ml})$. The solvent was evaporated and the crude product was purified by column chromatography (eluant: AcOEt/Hexane 1:10). Yield: 2.68 g, $95 \%$.

\section{General procedure for the aldol addition reactions}

To a solution of $5(282 \mathrm{mg}, 1 \mathrm{mmol})$ in DME $(3.5 \mathrm{~mL})$ at $-50{ }^{\circ} \mathrm{C}$ was added $\mathrm{n}-\mathrm{BuLi}(1.6 \mathrm{M}$ in hexanes, $0.75 \mathrm{~mL}, 1.2 \mathrm{mmol}, 1.2$ equiv). After stirring for $45 \mathrm{~min}$ at the same temperature the reaction was cooled to $-78{ }^{\circ} \mathrm{C}$ and a solution of the corresponding aldehyde (1.2-2 mmol, 1.2-2 equiv) in DME $(0.5 \mathrm{~mL})$ was added. The mixture was stirred for 45-60 min, followed by addition of aqueous $\mathrm{NH}_{4} \mathrm{Cl}$. The mixture was extracted with $\mathrm{CH}_{2} \mathrm{Cl}_{2}$ and the combined organic layers were washed with brine and dried over $\mathrm{MgSO}_{4}$. Evaporation of solvent gave the crude aldol products, which were purified by flash column chromatography (EtOAc/hexane 1:50) or recrystallized from hexane.

\section{General procedure for desilylation of adducts $7 / 8$}

To a solution of corresponding silylated aldol $(1 \mathrm{mmol})$ in $\mathrm{MeOH}(5 \mathrm{~mL})$ was added $\mathrm{HF}(49 \%$ in $\mathrm{H}_{2} \mathrm{O}, 0.5 \mathrm{~mL}$ ) at room temperature. The reaction mixture was stirred at the same temperature for 1 hour and then quenched with $\mathrm{NaHCO}_{3}$ (saturated solution, $1 \mathrm{~mL}$ ). Methylene chloride $(20 \mathrm{~mL}$ ) was added and the resulting mixture was washed with $3 \times 10 \mathrm{ml}$ of $\mathrm{NaHCO}_{3}$ (saturated solution). The combined organic phases were dried over magnesium sulfate, evaporated in vacuo and the residue purified by flash column chromatography (EtOAc/hexane 1:10) or crystallization to yield the expected desilylated aldol.

Optionally, desilylation of the adducts could also be effected by using a HF solution in $\mathrm{MeOH}$ as reagent and stirring of the mixture at room temperature for only $15 \mathrm{~min}$. After the same work-up, similar results as above were obtained.

\section{General procedure for the preparation of carboxylic acids}

To a solution of the corresponding $\alpha$ '-hydroxy ketone $9(1 \mathrm{mmol})$ in acetonitrile $(12 \mathrm{ml})$ at $0{ }^{\circ} \mathrm{C}$ was added dropwise a solution of cerium ammonium nitrate (CAN) (1.64 g, $3 \mathrm{mmol}$ ) in water $(6 \mathrm{ml})$ and the mixture was stirred at the same temperature for 1 hour. Then water $(3 \mathrm{ml})$ was added and the mixture was extracted with $\mathrm{CH}_{2} \mathrm{Cl}_{2}(2 \times 20 \mathrm{ml})$. The combined organic extracts 
were washed with $2 \mathrm{~N} \mathrm{NaOH}(2 \times 10 \mathrm{ml})$, dried over $\mathrm{MgSO}_{4}$, filtered, and the solvent evaporated to afford the starting $(\mathrm{R})-(+)$-camphor in $85-90 \%$ yield. The basic aqueous layer was acidified by adding concentrated $\mathrm{HCl}$ and then extracted with AcOEt $(2 \times 20 \mathrm{ml})$. The combined extracts were dried over $\mathrm{MgSO}_{4}$, filtered and the solvent removed under reduced pressure. The crude product was purified by column chromatography (eluant: ethyl acetate/hexane 1:30) to afford the corresponding carboxylic acid in $75-80 \%$ yields.

Synthesis of compound 17. To a solution of $\mathbf{1 6}^{27}(6.6 \mathrm{~g}, 23.3 \mathrm{mmol})$ in DME $(100 \mathrm{~mL})$ at $78{ }^{\circ} \mathrm{C}$ was added $\mathrm{n}-\mathrm{BuLi}$ (1.6 $\mathrm{M}$ in hexanes, $12.2 \mathrm{~mL}, 30.3 \mathrm{mmol}, 1.2$ equiv). After stirring for $1 \mathrm{~h}$ at the same temperature a solution of octanal $(7.3 \mathrm{~mL}, 46.6 \mathrm{mmol})$ in DME $(17 \mathrm{~mL})$ was added. The mixture was stirred for $2 \mathrm{~h}$, followed by addition of aqueous $\mathrm{NH}_{4} \mathrm{Cl}(75 \mathrm{~mL})$. The mixture was extracted with $\mathrm{CH}_{2} \mathrm{Cl}_{2}(2 \times 150 \mathrm{~mL})$ and the combined organic layers were dried over $\mathrm{MgSO}_{4}$. Evaporation of the solvent gave the crude aldol product, which was purified by flash column chromatography (EtOAc/hexane 1:40). Yield: $8.61 \mathrm{~g}$, 90\% (d.r. 96:4); oil. Data for major isomer: IR (KBr): v 3523, 2930, 1687, 1456, 1254, $1171 \mathrm{~cm}^{-1}$; ${ }^{1} \mathrm{H} \mathrm{NMR}(200 \mathrm{MHz}$, $\mathrm{CDCl}_{3}, 20^{\circ} \mathrm{C}, \delta 3.83(\mathrm{~m}, 1 \mathrm{H} ; \mathrm{CHOH}), 3.37$ (m, $\left.1 \mathrm{H} ; \mathrm{OH}\right), 3.19$ (dq, $1 \mathrm{H}, \mathrm{CHCH}_{3}, \mathrm{~J}=0.7 \mathrm{~Hz}, \mathrm{~J}$ ' = $7.3 \mathrm{~Hz}), 2.43\left(\mathrm{~d}_{\mathrm{b}}, 2 \mathrm{H}, \mathrm{CH}, \mathrm{J}=12.5 \mathrm{~Hz}\right), 1.83-0.76\left(\mathrm{~m}, 6 \mathrm{H}, 3 \mathrm{CH}_{2}\right.$, complex), $1.26(\mathrm{~s}, 12 \mathrm{H}, 6$ $\left.\mathrm{CH}_{2}\right), 1.10\left(\mathrm{~d}, 3 \mathrm{H}, \mathrm{CH}_{3} \mathrm{CH}, \mathrm{J}=7.0 \mathrm{~Hz}\right), 1.03\left(\mathrm{~s}, 3 \mathrm{H}, \mathrm{CH}_{3} \mathrm{C}\right), 0.95\left(\mathrm{~s}, 3 \mathrm{H}, \mathrm{CH}_{3} \mathrm{C}\right), 0.86(\mathrm{t}, 3 \mathrm{H}$, $\left.\mathrm{CH}_{3} \mathrm{CH}_{2}, \mathrm{~J}=6.6 \mathrm{~Hz}\right), 0.81\left(\mathrm{~s}, 3 \mathrm{H}, \mathrm{CH}_{3} \mathrm{C}\right), 0.11\left(\mathrm{~s}, 9 \mathrm{H} ;\left(\mathrm{CH}_{3}\right)_{3} \mathrm{Si}\right) ;{ }^{13} \mathrm{C} \mathrm{NMR}\left(50 \mathrm{MHz}, \mathrm{CDCl}_{3}\right.$, $\left.20{ }^{\circ} \mathrm{C}, \delta\right) 2.3,11.1,14.6,20.4,21.1,22.7,25.9,26.0,29.3,29.7,30.5,31.9,33.9,41.1,42.7$, 44.9, 52.2, 69.6, 91.7, 218.8 .

Desilylation of compound 17 to 18. To a solution of the silylated aldol 17 (8.61 g, $20.9 \mathrm{mmol})$ in $\mathrm{MeOH}(116.5 \mathrm{~mL})$ was added $\mathrm{HF}\left(49 \%\right.$ in $\left.\mathrm{H}_{2} \mathrm{O}, 28 \mathrm{~mL}\right)$ at room temperature. The reaction mixture was stirred at the same temperature for 3 hours and then was cooled to $0{ }^{\circ} \mathrm{C}$ and quenched with a saturated solution of $\mathrm{NaHCO}_{3}$ until neutralization. Methylene chloride $(150 \mathrm{~mL})$ was added and the resulting mixture was washed with $3 \times 50 \mathrm{ml}$ of $\mathrm{NaHCO}_{3}$ (saturated solution). The organic phase was dried over magnesium sulfate, evaporated in vacuo and the residue purified by crystallization to yield the expected desilylated aldol. Yield: $5.76 \mathrm{~g}, 81 \%$; m.p. $97-99{ }^{\circ} \mathrm{C} ;[\alpha]_{\mathrm{D}}{ }^{25}=91.0\left(c=1.0, \mathrm{CH}_{2} \mathrm{Cl}_{2}\right)$; IR (KBr): v 3426, 2858, 1690, 1455, 1388, $1311 \mathrm{~cm}^{-1} ;{ }^{1} \mathrm{H}$ NMR (200 MHz, $\left.\mathrm{CDCl}_{3}, 20{ }^{\circ} \mathrm{C}, \delta\right) 3.73(\mathrm{~m}, 1 \mathrm{H} ; \mathrm{CHOH}), 3.20(\mathrm{~m}, 1 \mathrm{H} ; \mathrm{OH}), 3.09$ $\left(\mathrm{dq}, 1 \mathrm{H} ; \mathrm{CHCH}_{3}, \mathrm{~J}=1.5 \mathrm{~Hz}, \mathrm{~J}\right.$ ' $\left.=6.8 \mathrm{~Hz}\right), 2.19\left(\mathrm{~d}_{\mathrm{b}}, 1 \mathrm{H} ; \mathrm{CH}\right), 1.89-0.82\left(\mathrm{~m}, 6 \mathrm{H}, 3 \mathrm{CH}_{2}\right.$, complex), $1.24\left(\mathrm{~s}_{\mathrm{b}}, 12 \mathrm{H}, 6 \mathrm{CH}_{2}\right), 1.09\left(\mathrm{~s}, 3 \mathrm{H}, \mathrm{CH}_{3} \mathrm{C}\right), 1.07\left(\mathrm{~d}, 3 \mathrm{H}, \mathrm{CH}_{3} \mathrm{CH}, \mathrm{J}=5.5 \mathrm{~Hz}\right), 0.91$ (s, $\left.3 \mathrm{H}, \mathrm{CH}_{3} \mathrm{C}\right), 0.84\left(\mathrm{t}, 3 \mathrm{H}, \mathrm{CH}_{3} \mathrm{CH}_{2}, \mathrm{~J}=6.6 \mathrm{~Hz}\right), 0.82\left(\mathrm{~s}, 3 \mathrm{H}, \mathrm{CH}_{3} \mathrm{C}\right) ;{ }^{13} \mathrm{C} \mathrm{NMR}\left(50 \mathrm{MHz}, \mathrm{CDCl}_{3}\right.$, $\left.20{ }^{\circ} \mathrm{C}, \delta\right) 10.5,10.9,14.1,20.5,20.9,22.7,26.1,26.6,29.2,29.6,30.3,31.8,34.0,41.6,44.8$, 44.9, 50.7, 52.6, 70.4, 88.3, 219.7. Anal. Calcd for $\mathrm{C}_{21} \mathrm{H}_{38} \mathrm{O}_{3}$ (338.59): C 74.49, H 11.33; found: C 74.51, H 11.31.

Preparation of 20. Oxalyl chloride $(0.33 \mathrm{~mL}, 4.5 \mathrm{mmol})$ was added dropwise to a solution of the carboxylic acid $\mathbf{1 9}^{23 \mathrm{~d}}\left(0.71 \mathrm{~g}, 1.5 \mathrm{mmol}\right.$, obtained as stated above) in $\mathrm{CH}_{2} \mathrm{Cl}_{2}(6 \mathrm{~mL})$ cooled to $0{ }^{\circ} \mathrm{C}$. The mixture was stirred at room temperature for $3 \mathrm{~h}$ then the solvent and excess of oxalyl chloride were removed under reduced pressure. The residue was dissolved in $\mathrm{CH}_{2} \mathrm{Cl}_{2}(2.5 \mathrm{~mL})$ and the solution was added drop-wise to a solution of 18 (0.44 g, $1.3 \mathrm{mmol})$ and DMAP (0.48 g, 
$3.9 \mathrm{mmol})$ in $\mathrm{CH}_{2} \mathrm{Cl}_{2}(7.5 \mathrm{~mL})$ cooled to $0{ }^{\circ} \mathrm{C}$. The resulting mixture was stirred at room temperature for $3 \mathrm{~h}$ and then washed with $1 \mathrm{~N} \mathrm{HCl}(3 \times 10 \mathrm{~mL})$ and with a saturated solution of $\mathrm{NaHCO}_{3}(2 \times 10 \mathrm{~mL})$. The organic layer was dried over $\mathrm{MgSO}_{4}$ and the solvent was removed under reduced pressure. The residue was purified by column chromatography (EtOAc-hexane 1:70) to afford the product 20. Yield: $0.84 \mathrm{~g}, 82 \%$; oil; $[\alpha]_{\mathrm{D}}{ }^{25}=23.3\left(c=1.0, \mathrm{CH}_{2} \mathrm{Cl}_{2}\right)$; IR $(\mathrm{KBr})$ : v 3467, 2955, 1731, 1705, 1685, 1460, $1255 \mathrm{~cm}^{-1}$; ${ }^{1} \mathrm{H}$ NMR (200 MHz, DMSO-d $\left.6,90{ }^{\circ} \mathrm{C}, \delta\right)$ 7.33-7.11 (m, 10H, $\left.2 \mathrm{C}_{6} \mathrm{H}_{5}\right), 5.08(\mathrm{q}, 1 \mathrm{H}, \mathrm{COOCH}, \mathrm{J}=5.9 \mathrm{~Hz}), 4.96\left(\mathrm{~d}, 2 \mathrm{H}, \mathrm{CH}_{2} \mathrm{Ph}\right), 4.38(\mathrm{~m}$, 1H, CHOSi), 4.17 (m, 1H, CHNCbz), 3.32 (m, 1H, $\left.\mathrm{CHCH}_{3}\right), 3.10$ (dd, $1 \mathrm{H} \mathrm{COHCH,} \mathrm{J} \mathrm{=} \mathrm{4.4} \mathrm{Hz,}$ $\mathrm{J}$ ' = 14.5 Hz), $3.03(\mathrm{~m}, 1 \mathrm{H} ; \mathrm{OH}), 2.88\left(\mathrm{~d}_{\mathrm{b}}, 1 \mathrm{H} ; \mathrm{COHCH}, \mathrm{J}=12.1 \mathrm{~Hz}\right), 2.68(\mathrm{dd}, 1 \mathrm{H} ; \mathrm{PhHCH}, \mathrm{J}=$ $4.8 \mathrm{~Hz}, \mathrm{~J}$ ' $=15.8 \mathrm{~Hz}), 2.65\left(\mathrm{~s}, 3 \mathrm{H}, \mathrm{NCH}_{3}\right), 2.46(\mathrm{dd}, 1 \mathrm{H}, \mathrm{PhHCH}, \mathrm{J}=4.4 \mathrm{~Hz}, \mathrm{~J}$ ' = $13.4 \mathrm{~Hz}), 2.07$ $\left(\mathrm{d}_{\mathrm{b}}, 2 \mathrm{H}, \mathrm{CH}\right), 1.84-0.81\left(\mathrm{~m}, 6 \mathrm{H}, 3 \mathrm{CH}_{2}\right.$, complex), $1.25\left(\mathrm{~s}_{\mathrm{b}}, 12 \mathrm{H}, 6 \mathrm{CH}_{2}\right), 1.05\left(\mathrm{~d}, 3 \mathrm{H}, \mathrm{CH}_{3} \mathrm{CH}, \mathrm{J}\right.$ $=7.0 \mathrm{~Hz}), 0.96\left(\mathrm{~s}, 3 \mathrm{H}, \mathrm{CH}_{3} \mathrm{C}\right), 0.92\left(\mathrm{~s}, 9 \mathrm{H} ;\left(\mathrm{CH}_{3}\right)_{3} \mathrm{C}\right), 0.87\left(\mathrm{t}, 3 \mathrm{H}, \mathrm{CH}_{3} \mathrm{CH}_{2}, \mathrm{~J}=5.9 \mathrm{~Hz}\right), 0.81(\mathrm{~s}$, $\left.3 \mathrm{H}, \mathrm{CH}_{3} \mathrm{C}\right), 0.13\left(\mathrm{~s}, 3 \mathrm{H} ; \mathrm{CH}_{3} \mathrm{Si}\right), 0.11\left(\mathrm{~s}, 3 \mathrm{H} ; \mathrm{CH}_{3} \mathrm{Si}\right) ;{ }^{13} \mathrm{C} \mathrm{NMR}\left(50 \mathrm{MHz}, \mathrm{CDCl}_{3}, 20{ }^{\circ} \mathrm{C}, \delta\right)$ both conformers $-4.9,-4.8,-4.2,-4.1,10.3,10.4,10.7,11.9,12.5,13.8,14.1,17.9,20.3,20.9,22.6$, 25.9, 26.0, 26.1, 26.8, 27.1, 29.0, 29.1, 29.3, 29.6, 31.6, 31.7, 32.6, 34.3, 40.0, 41.5, 41.6, 44.6, $44.8,49.9,50.0,50.3,52.6,52.8,66.5,67.2,69.5,69.7,73.6,73.9,87.0,87.2,125.9,126.1$, $127.1,127.5,127.7,128.0,128.1,128.2,128.7,128.8,136.4,136.9,138.5,138.8,156.2,156.3$, $170.5,170.8,214.2,214.4$.

Preparation of carboxylic acid 21. To a solution of $20(1.47 \mathrm{~g}, 1.86 \mathrm{mmol})$ in acetonitrile $(20 \mathrm{ml})$ at $0{ }^{\circ} \mathrm{C}$ was added dropwise a solution of cerium ammonium nitrate (CAN) (3.10 g, $5.58 \mathrm{mmol})$ in water $(10 \mathrm{ml})$ and the mixture was stirred at the same temperature for 5 minutes. Then water $(10 \mathrm{ml})$ was added and the mixture was extracted with $\mathrm{CH}_{2} \mathrm{Cl}_{2}(2 \times 20 \mathrm{ml})$. The combined organic extracts were dried over $\mathrm{MgSO}_{4}$, filtered, and the solvent evaporated. The crude product was purified by column chromatography (eluant: ethyl acetate/hexane 1:10) to afford the corresponding carboxylic acid. Yield: $0.99 \mathrm{~g}, 81 \%$; oil; $[\alpha]_{\mathrm{D}}{ }^{25}=-3.0\left(c=1.0, \mathrm{CH}_{2} \mathrm{Cl}_{2}\right)$; IR (KBr): v 2950, 2853, 1742, 1701, 1460, $1255 \mathrm{~cm}^{-1} ;{ }^{1} \mathrm{H}$ NMR (200 MHz, DMSO-d $\left.6,90{ }^{\circ} \mathrm{C}, \delta\right)$ 7.26-7.02 (m, 10H, $\left.2 \mathrm{C}_{6} \mathrm{H}_{5}\right), 5.03(\mathrm{q}, 1 \mathrm{H}, \mathrm{COOCH}, \mathrm{J}=6.2 \mathrm{~Hz}), 4.88\left(\mathrm{~s}_{\mathrm{b}}, 2 \mathrm{H}, \mathrm{CH}_{2} \mathrm{Ph}\right), 4.29(\mathrm{~m}$, 1H, CHOSi), 4.07 (m, 1H, CHNCbz), 3.01 (dd, 1H COHCH, J = 3.7 Hz, J' = $13.9 \mathrm{~Hz}), 2.81$ (d $1 \mathrm{H}$; $\mathrm{COHCH}, \mathrm{J}=11.7 \mathrm{~Hz}), 2.61-2.32\left(\mathrm{~m}, 3 \mathrm{H} ; \mathrm{PhCH}_{2}, \mathrm{CHCH}_{3}\right), 2.56\left(\mathrm{~s}, 3 \mathrm{H}, \mathrm{NCH}_{3}\right), 1.49(\mathrm{~m}$, $\left.2 \mathrm{H}, 1 \mathrm{CH}_{2}\right), 1.19\left(\mathrm{~s}, 10 \mathrm{H}, 5 \mathrm{CH}_{2}\right), 0.99\left(\mathrm{~d}, 3 \mathrm{H}, \mathrm{CH}_{3} \mathrm{CH}, \mathrm{J}=7.0 \mathrm{~Hz}\right), 0.84\left(\mathrm{~s}, 9 \mathrm{H} ;\left(\mathrm{CH}_{3}\right){ }_{3} \mathrm{C}\right), 0.79$ $\left(\mathrm{t}, 3 \mathrm{H}, \mathrm{CH}_{3} \mathrm{CH}_{2}, \mathrm{~J}=7.0 \mathrm{~Hz}\right), 0.06\left(\mathrm{~s}, 3 \mathrm{H} ; \mathrm{CH}_{3} \mathrm{Si}\right), 0.03\left(\mathrm{~s}, 3 \mathrm{H} ; \mathrm{CH}_{3} \mathrm{Si}\right) ;{ }^{13} \mathrm{C} \mathrm{NMR}(50 \mathrm{MHz}$, $\mathrm{CDCl}_{3}, 20{ }^{\circ} \mathrm{C}, \delta$ ) both conformers $0.00,0,08,0.50,0.73,16.2,17.1,18.9,22.8,27.5,30.4,30.7$, 34.0, 34.2, 34.5, 36.6, 36.7, 39.1, 39.5, 44.9, 45.4, 46.7, 47.3, 47.8, 48.1, 71.5, 72.4, 74.4, 74.8, $74.9,79.1,79.3,79.4,79.5,130.9,131.0,132.1,132.4,132.7,132.9,133.1,133.4,133.5,133.7$, 141.0, 141.6, 143.5, 161.1, 161.8, 175.0, 175.3.

Preparation of 23. Oxalyl chloride $(0.30 \mathrm{~mL}, 4.5 \mathrm{mmol})$ was added dropwise to a solution of 21 (0.91 g, $1.38 \mathrm{mmol})$ in $\mathrm{CH}_{2} \mathrm{Cl}_{2}(6 \mathrm{~mL})$ cooled to $0{ }^{\circ} \mathrm{C}$. The mixture was stirred at room temperature for $3 \mathrm{~h}$ then the solvent and excess oxalyl chloride were removed under reduced pressure. The residue thus obtained was dissolved in $\mathrm{CH}_{2} \mathrm{Cl}_{2}(1.5 \mathrm{~mL})$ and the resulting solution was added to a cooled $\left(0^{\circ} \mathrm{C}\right)$ solution of $(2 \mathrm{~S})$-benzyl 2-hydroxy-3-methyl butyrate (22) (0.28 g, 
$1.35 \mathrm{mmol})$ and DMAP (0.50 g, $4.05 \mathrm{mmol})$ in $\mathrm{CH}_{2} \mathrm{Cl}_{2}(7.5 \mathrm{~mL})$. The resulting solution was stirred at room temperature for $3 \mathrm{~h}$ and then washed with $1 \mathrm{~N} \mathrm{HCl}(3 \mathrm{x} 10 \mathrm{~mL})$ and with a saturated solution of $\mathrm{NaHCO}_{3}(2 \times 10 \mathrm{~mL})$. The organic layer was dried over $\mathrm{MgSO}_{4}$, filtered and the solvent removed under reduced pressure. The residue was purified by column chromatography (ethyl acetate/hexane 1:50) to afford the coupling diester. Yield: $1.03 \mathrm{~g}, 90 \%$; oil; $[\alpha]_{\mathrm{D}}{ }^{25}=-33.0\left(c=1.0, \mathrm{CH}_{2} \mathrm{Cl}_{2}\right)$; IR (KBr): v 2955, 2925, 1741, 1701, 1455, $1250 \mathrm{~cm}^{-1} ;{ }^{1} \mathrm{H}$ NMR (200 MHz, DMSO-d $\left.6,90{ }^{\circ} \mathrm{C}, \delta\right)$ 7.41-7.09 (m, 15H, $\left.3 \mathrm{C}_{6} \mathrm{H}_{5}\right), 5.16\left(\mathrm{~s}, 2 \mathrm{H}, \mathrm{CH}_{2} \mathrm{Ph}\right), 5.04$ (q, $1 \mathrm{H}, \mathrm{COOCH}, \mathrm{J}=6.2 \mathrm{~Hz}), 4.93\left(\mathrm{~s}, 2 \mathrm{H}, \mathrm{CH}_{2} \mathrm{Ph}\right), 4.82(\mathrm{~d}, 1 \mathrm{H}, \mathrm{CHCOOBn}, \mathrm{J}=4.8 \mathrm{~Hz}), 4.36(\mathrm{~m}$, 1H, CHOSi), 4.14 (m, 1H, CHNCbz), 3.07 (dd, 1H COHCH, J = 4.0 Hz, J' = 14.3 Hz), 2.86 (d $1 \mathrm{H}$; $\mathrm{COHCH}, \mathrm{J}=14.3 \mathrm{~Hz}), 2.79-2.40\left(\mathrm{~m}, 3 \mathrm{H}, \mathrm{CHCH}_{3}, \mathrm{PhCH}_{2}\right), 2.62\left(\mathrm{~s}, 3 \mathrm{H} ; \mathrm{NCH}_{3}\right), 2.15(\mathrm{~m}$, $\left.1 \mathrm{H}, \mathrm{CH}\left(\mathrm{CH}_{3}\right)_{2}\right), 1.56\left(\mathrm{~m}, 2 \mathrm{H}, 1 \mathrm{CH}_{2}\right), 1.24\left(\mathrm{~s}, 10 \mathrm{H}, 5 \mathrm{CH}_{2}\right), 1.09\left(\mathrm{~d}, 3 \mathrm{H}, \mathrm{CH}_{3} \mathrm{CH}, \mathrm{J}=7.0 \mathrm{~Hz}\right)$, $0.93\left(\mathrm{~d}, 3 \mathrm{H}, \mathrm{CH}\left(\mathrm{CH}_{3}\right)_{2}, \mathrm{~J}=6.6 \mathrm{~Hz}\right), 0.91\left(\mathrm{~s}, 9 \mathrm{H} ;\left(\mathrm{CH}_{3}\right)_{3} \mathrm{C}\right), 0.90\left(\mathrm{~d}, 3 \mathrm{H}, \mathrm{CH}\left(\mathrm{CH}_{3}\right)_{2}, \mathrm{~J}=6.6 \mathrm{~Hz}\right)$, $0.86\left(\mathrm{t}, 3 \mathrm{H}, \mathrm{CH}_{3} \mathrm{CH}_{2}, \mathrm{~J}=6.6 \mathrm{~Hz}\right), 0.12\left(\mathrm{~s}, 3 \mathrm{H} ; \mathrm{CH}_{3} \mathrm{Si}\right), 0.09\left(\mathrm{~s}, 3 \mathrm{H} ; \mathrm{CH}_{3} \mathrm{Si}\right) ;{ }^{13} \mathrm{C} \mathrm{NMR}(50 \mathrm{MHz}$, $\mathrm{CDCl}_{3}, 20{ }^{\circ} \mathrm{C}, \delta$ ) both conformers $-4.8,-4.7,-4.0,12.7,13.0,14.1,17.2,18.0,18.8,22.6,25.4$, 25.9, 29.2, 29.4, 30.1, 31.8, 32.0, 34.4, 40.0, 42.8, 43.1, 66.5, 66.8, 67.2, 69.8, 70.1, 74.4, 74.5, $76.7,126.0,126.1,127.2,127.6,127.8,128.0,128.2,128.3,128.4,128.5,128.8,135.2,135.3$, $136.3,136.8,138.6,138.8,156.1,169.0,170.6,173.1,173.2$.

To a solution of the coupling diester $(0.85 \mathrm{~g}, 1 \mathrm{mmol})$ in THF $(20 \mathrm{~mL})$, complex HF/Py $(4.2 \mathrm{~mL})$ was added at room temperature and the mixture was stirred for 4 hours at the same temperature. The reaction was quenched with a saturated solution of $\mathrm{NaHCO}_{3}$ until neutralization and the mixture was extracted with methylene chloride $(2 \times 15 \mathrm{~mL})$. The organic phase was dried over magnesium sulfate, evaporated in vacuo and the residue purified by flash column chromatography (EtOAc/hexane 1:10). Yield: $0.55 \mathrm{~g}, 75 \%$. oil; $[\alpha]_{\mathrm{D}}{ }^{25}=-16.0(c=1.0$, $\mathrm{CH}_{2} \mathrm{Cl}_{2}$ ); IR (KBr): v 3478, 2925, 1737, 1701, 1455, 1265, $1194 \mathrm{~cm}^{-1}$; ${ }^{1} \mathrm{H}$ NMR (200 MHz, DMSO-d $\left._{6}, 90{ }^{\circ} \mathrm{C}, \delta\right) 7.36-7.16\left(\mathrm{~m}, 15 \mathrm{H}, 3 \mathrm{C}_{6} \mathrm{H}_{5}\right), 5.17\left(\mathrm{~s}, 2 \mathrm{H}, \mathrm{CH}_{2} \mathrm{Ph}\right), 5.07(\mathrm{q}, 1 \mathrm{H}, \mathrm{COOCH}, \mathrm{J}=$ $6.2 \mathrm{~Hz}), 4.94\left(\mathrm{~s}_{\mathrm{b}}, 2 \mathrm{H}, \mathrm{CH}_{2} \mathrm{Ph}\right), 4.83(\mathrm{~d}, 1 \mathrm{H}, \mathrm{CHCOOBn}, \mathrm{J}=4.8 \mathrm{~Hz}), 4.08(\mathrm{~m}, 2 \mathrm{H}, \mathrm{CHOH}$, $\mathrm{CHNCbz}), 3.15\left(\mathrm{~d}_{\mathrm{b}}, 1 \mathrm{H}, \mathrm{COHCH}, \mathrm{J}=11.7 \mathrm{~Hz}\right), 3.02(\mathrm{~s}, 1 \mathrm{H}, \mathrm{OH}), 2.80\left(\mathrm{~m}, 1 \mathrm{H}, \mathrm{CHCH}_{3}\right), 2.79$ $(\mathrm{dd}, 1 \mathrm{H} \mathrm{COHCH}, \mathrm{J}=7.3 \mathrm{~Hz}, \mathrm{~J}$ ' = $13.9 \mathrm{~Hz}), 2.67\left(\mathrm{~s}, 3 \mathrm{H} ; \mathrm{NCH}_{3}\right), 2.50-2.27\left(\mathrm{~m}, 2 \mathrm{H}, \mathrm{PhCH}_{2}\right), 2.19$ $\left(\mathrm{m}, 1 \mathrm{H}, \mathrm{CH}\left(\mathrm{CH}_{3}\right)_{2}\right), 1.58\left(\mathrm{~m}, 2 \mathrm{H}, 1 \mathrm{CH}_{2}\right), 1.26\left(\mathrm{~s}, 10 \mathrm{H}, 5 \mathrm{CH}_{2}\right), 1.12\left(\mathrm{~d}, 3 \mathrm{H}, \mathrm{CH}_{3} \mathrm{CH}, \mathrm{J}=7.0\right.$ $\mathrm{Hz}), 0.95\left(\mathrm{~d}, 3 \mathrm{H}, \mathrm{CH}\left(\mathrm{CH}_{3}\right)_{2}, \mathrm{~J}=6.6 \mathrm{~Hz}\right), 0.92\left(\mathrm{~d}, 3 \mathrm{H}, \mathrm{CH}\left(\mathrm{CH}_{3}\right)_{2}, \mathrm{~J}=6.6 \mathrm{~Hz}\right), 0.87(\mathrm{t}, 3 \mathrm{H}$, $\left.\mathrm{CH}_{3} \mathrm{CH}_{2}, \mathrm{~J}=6.6 \mathrm{~Hz}\right) ;{ }^{13} \mathrm{C} \mathrm{NMR}\left(50 \mathrm{MHz}, \mathrm{CDCl}_{3}, 20{ }^{\circ} \mathrm{C}, \delta\right)$ both conformers 11.4, 11.7, 14.1, 14.2 , 17.2, 18.8, 22.6, 25.5, 25.6, 29.1, 29.3, 30.0, 31.1, 31.3, 31.7, 33.2, 39.2, 42.1, 42.3, 66.8, $66.9,67.0,67.2,68.9,69.7,74.3,76.9,126.0,126.1,127.3,127.7,127.8,128.0,128.2,128.3$, $128.4,128.8,128.9,135.0,135.1,136.2,136.7,138.4,138.5,156.2,156.5,169.2,169.3,171.7$, 171.8, 173.4 .

Synthesis of Hapalosin. A round-bottom flask containing a mixture of $23(0.18 \mathrm{~g}, 0.25 \mathrm{mmol})$ and $\mathrm{Pd} / \mathrm{C}(10 \% \mathrm{Pd}, 0.027 \mathrm{~g}, 0.025 \mathrm{mmol})$ in trifluoroacetic acid $(5 \mathrm{~mL})$ was stirred for 1 hour at $25{ }^{\circ} \mathrm{C}$ under a balloon full of $\mathrm{H}_{2}$. Then the flask was purged with $\mathrm{N}_{2}$ and the mixture was filtered through a short column of celite and washed well with $\mathrm{CH}_{2} \mathrm{Cl}_{2}$. The solvent was removed under reduced pressure. DMF $(220 \mathrm{~mL})$ was then added to dissolve the residue obtained and to the 
resulting solution were added, successively, diphenyl phosphoryl azide DPPA $(0.15 \mathrm{~mL}, 0.66$ mmol $)$ and ${ }^{\mathrm{i}} \operatorname{Pr}_{2} \mathrm{NEt}(0.23 \mathrm{ml}, 1.32 \mathrm{mmol})$ at $0{ }^{\circ} \mathrm{C}$. The mixture was stirred at this temperature for $3 \mathrm{~h}$, then at room temperature for 4 days. The resulting mixture was partitioned between ethyl acetate $(200 \mathrm{~mL})$ and water $(100 \mathrm{~mL})$. The organic layer was washed with brine $(150 \mathrm{~mL})$, dried over $\mathrm{MgSO}_{4}$, filtered and evaporated. The residue was purified by flash chromatography (EtOAc/hexane 1:20). Yield: $0.052 \mathrm{~g}, 25 \%$. Data of the mixture of two conformers: $[\alpha]_{\mathrm{D}}{ }^{25}=-40$ $\left(c=1.0, \mathrm{CH}_{2} \mathrm{Cl}_{2}\right)$; IR (neat): $v=3411,2959,1731,1631,1496,1456,1151 \mathrm{~cm}^{-1}$; ${ }^{1} \mathrm{H}$ NMR $(500$ $\left.\mathrm{MHz}, \mathrm{CDCl}_{3}, \delta\right) 7.34(\mathrm{dd}, J=7.0,7.7 \mathrm{~Hz}, 2 \mathrm{H}), 7.26-7.19(\mathrm{~m}, 3 \mathrm{H}), 5.13(\mathrm{~m}, 1 \mathrm{H}), 4.32(\mathrm{~d}, J=8.4$ $\mathrm{Hz}, 1 \mathrm{H}), 3.86(\mathrm{~m}, 1 \mathrm{H}), 3.70(\mathrm{dt}, J=8.8,2.5 \mathrm{~Hz}, 1 \mathrm{H}), 3.41(\mathrm{dd}, J=13.9,2.5,1 \mathrm{H}), 3.24(\mathrm{~m}, 1 \mathrm{H})$, $2.93(\mathrm{dd}, J=5.3,17.9 \mathrm{~Hz}, 1 \mathrm{H}), 2.86(\mathrm{~s}, 3 \mathrm{H}), 2.65(\mathrm{~m}, 1 \mathrm{H}), 2.62(\mathrm{~m}, 1 \mathrm{H}), 2.02(\mathrm{~m}, 1 \mathrm{H}), 1.92(\mathrm{~m}$, $1 \mathrm{H}), 1.62(\mathrm{~m}, 1 \mathrm{H}), 1.40-1.20\left(\mathrm{~m}_{\mathrm{b}}, 10 \mathrm{H}\right), 1.18(\mathrm{~d}, J=6.9 \mathrm{~Hz}, 3 \mathrm{H}), 0.89(\mathrm{~m}, 3 \mathrm{H}), 0.56(\mathrm{~d}, J=6.9$ $\mathrm{Hz}, 3 \mathrm{H}), 0.24(\mathrm{~d}, J=6.9 \mathrm{~Hz}, 3 \mathrm{H}) ;{ }^{13} \mathrm{C} \mathrm{NMR}\left(125 \mathrm{MHz}, \mathrm{CDCl}_{3}, \delta\right)$ 172.6, 171.7, 170.4, 170.0, $168.6,168.5,137.7,137.3,129.1,128.9,128.7,128.2,126.9,126.2,82.9,76.5,74.8,73.8,70.1$, $61.3,59.0,40.9,40.7,40.3,37.3,36.2,35.3,31.7,31.7,30.6,29.4,29.2,29.1,28.9,28.1,26.0$, $25.2,22.6,19.6,18.3,17.6,16.6,14.1,12.1,10.4$; MS (ESI, $m / z)$ : calcd for $\mathrm{C}_{28} \mathrm{H}_{44} \mathrm{NO}_{6}\left(\mathrm{M}+\mathrm{H}^{+}\right)$, 490.32; found, 490.3 .

\section{Supplementary information}

Tabulated data used in Figure 1; characterization data for aldols $\mathbf{7}$ and $\mathbf{8}$ and carboxylic acids $\mathbf{1 1}$ and 12; representative ${ }^{1} \mathrm{H}$ and ${ }^{13} \mathrm{C}$ spectra, and ORTEP diagrams of $\mathbf{8 d}$, 7k and $\mathbf{8 k}$.

\section{Acknowledgements}

This work was finantially supported by the Universidad del País Vasco, Gobierno Vasco, and by MEC. Grants to M. C. G.-R. from Gobierno Vasco and to P. B. from MEC are acknowledged.

\section{References and Notes}

1. Modern Aldol Reactions; Mahrwald, R., Ed; Wiley-VCH: Weinhein, 2004.

2. (a) Palomo, C.; Oiarbide, M.; García, J. M. Chem. Soc. Rev. 2004, 33, 65. (b) Palomo, C.; Oiarbide, M.; García, J. M. Chem. Eur. J. 2002, 8, 36.

3. Alcaide, B.; Almendros, P. Eur. J. Org. Chem. 2002, 1595.

4. Pioneering work by using proline and congeners as catalysts: (a) List, B.; Lerner, R. A.; Barbas III, C. F. J. Am. Chem. Soc. 2000, 122, 2395. (b) Notz, W.; List, B. J. Am. Chem. Soc. 2000, 122, 7386. (c) Sakthivel, K.; Notz, W.; Bui, T.; Barbas III, C. F. J. Am. Chem. Soc. 2001, 123, 5260. (d) List, B.; Pojarliev, P.; Castello, C. Org. Lett. 2001, 3, 573. 
Selected examples using metallic catalysts: (a) Kumagai, S. Matsunaga, T. Kinoshita, S. Harada, Okada, S.; Sakamoto, S.; Yamaguzhi, K.; Shibasaki, M. J. Am. Chem. Soc. 2003, 125, 2169 and references therein. (b) Trost, B. M.; Fettes, A.; Shireman, B. T. J. Am. Chem. Soc. 2004, 126, 2660 and references therein. (c) Evans, D. A.; Downey, C. W.; Hubbs, J. L. J. Am. Chem. Soc. 2003, 125, 8706.

5. (a) Nakadai, M.; Saito, S.; Yamamoto, H. Tetrahedron 2002, 58, 8167. (b) Mahrwald, R. Org. Lett. 2000, 2, 4011. (c) Mahrwald, R.; Ziemer, B. Tetrahedron Lett. 2002, 43, 4459.

6. For exceptions, see. (a) Northrup, A. B.; MacMillan, D. W. C. J. Am. Chem. Soc., 2002, 124, 6798. (b) Evans, D. A.; Downey, C. W.; Hubbs, J. L. J. Am. Chem. Soc. 2003, 125, 8706.

7. a) Cowden, C. J.; Paterson, I. Org. React. 1997, 51, 1. (b) Paterson, I.; Cowden, C. J.; Wallace, D. J. In Modern Carbonyl Chemistry; J. Otera, Ed.; Wiley-VCH: Weinheim, 2000; pp 249-297. c) Abiko, A. Acc. Chem. Res. 2004, 37, 387.

8. Heathcock, C. H. In Comprehensive Organic Synthesis, Vol 2; Trost, B. M.; Fleming, I.; Heathcock, C. H., Ed.; Pergamon: Oxford, 1991; pp 181-238.

9. For a detailed information on this subject, see: (a) Evans, D. A.; Takacs, J. M.; McGee, L. R.; Ennis, M. D.; Mathre, D. J.; Bartoli, J. Pure Appl. Chem. 1981, 53, 1109. (b) NerzStormes, M.; Thornton, E. R. J. Org. Chem. 1991, 56, 2489.

10. Aldol reactions: (a) Palomo, C.; González, A.; García, J. M.; Landa, C.; Oiarbide, M.; Rodríguez, S.; Linden, A. Angew. Chem, Int. Ed. 1998, 37, 180. (b) Palomo, C.; Oiarbide, M.; Aizpurua, J. M.; González, A.; García, J. M.; Landa, C.; Odriozola, I.; Linden, A. J. Org. Chem. 1999, 64, 8193. Mannich reactions: (c) Palomo, C.; Oiarbide, M.; Landa, A.; González-Rego, M. C.; García, J. M.; González, A.; Odriozola, J. M.; Martín-Pastor, M.; Linden, A. J. Am. Chem. Soc. 2002, 124, 8637.

11. For detailed information on the stereochemical problem of $\alpha$-unsubstituted enolates, see: (a) Braun, M. Angew. Chem., Int. Ed. 1987, 26, 24. (b) Braun M. In Advances in Carbanion Chemistry, Snieckus, V., Ed.; Jai: London, 1992; Vol. 1, p 177. (c) Braun, M.; Sacha, H. J. prakt. Chem. 1993, 335, 653.

12. Palomo, C.; Oiarbide, M.; Mielgo, A.; González, A.; García, J. M.; Landa, C.; Lecumberri, A.; Linden, A. Org. Lett. 2001, 3, 3249.

13. Wilkinson, H. S.; Grover, P. T.; Vandenbossche, C. P.; Bakale, R. P.; Bhongle, N. N.; Wald, S. A.; Senanayake, C. H. Org. Lett. 2001, 3, 553.

14. 1,1,1-Triphenylmethyl group: (a) Seebach, D.; Ertas, M.; Locher, R.; Schweizer, W. B. Helv. Chim. Acta 1985, 68, 264. (b) Ertas, M.; Seebach, D. Helv. Chim. Acta 1985, 68, 961. (c) Seebach, D.; Locher, R. Angew. Chem., Int. Ed. 1979, 18, 957.

15. 2,6-Di-tert-butyl-4-methoxyphenyl: (a) Heathcock, C. H.; Pirrung, M. C.; Montgomery, S. H.; Lampe, J. Tetrahedron 1981, 37, 4087. 2,2,6,6-Tetramethylpyperidines: (b) Ref. 14c. Tris(2,6-diphenylbenzyl)silyl group: (c) Iwasaki, A.; Kondo, Y.; Maruoka, K. J. Am. Chem. Soc. 2000, 122, 10238. 
16. (a) Cainelli, G.; Giacomini, D. ; Galleti, P.; Orioli, P. ; Paradisi, F. Eur. J. Org. Chem. 2000, 3619. (b) Cainelli, G.; Giacomini, D. ; Galleti, P.; Marini, A. Angew. Chem., Int. Ed. 1996, 35, 2849. (c) Cainelli, G.; Galleta, P.; Giacomini, D.; Orioli, P. Tetrahedron Lett. 2001, 42, 7383.

17. See the Supporting Information for details.

18. This result would be in agreement with the fact that the $\mathrm{OSi}^{\mathrm{i}} \mathrm{Pr}_{3}$ group has no ability to chelate. See: (a) Chen, X.; Hortelano, E. R.; Eliel, E. L.; Frye, S. V. J. Am. Chem. Soc. 1990, 112, 6130. (b) Galobardes, M.; Gascón, M.; Mena, M.; Romea, P.; Urpí, F.; Vilarrasa, J. Org. Lett. 2000, 2, 2599.

19. Slightly lower levels of diastereoselection were observed when the lithium enolate of 5 was generated under the more standard LDA-TMEDA or LDA-HMPA conditions in THF.

20. Observed values: $9[\alpha]_{\mathrm{D}}{ }^{25}=+10.8\left(\mathrm{CHCl}_{3}, c=1\right), \mathbf{1 0}[\alpha]_{\mathrm{D}}{ }^{25}=+28.5\left(\mathrm{CHCl}_{3}, c=1\right)$. Literature data for 9: $+9.1\left(\mathrm{CHCl}_{3}, c=2.2\right)$; for $10+28.5\left(\mathrm{CHCl}_{3}, c=1.2\right)$ (Heathcock, C. H.; White, C. T.; Morrison, J. J.; Van Derveer, D. J. J. Org. Chem. 1981, 46, 1296).

21. CCDC-204883-204885 contain the supplementary crystallographic data for this paper. These data can be obtained free of charge from The Cambridge Crystallographic Data Centre via www.ccdc.cam.ac.uk/data_request/cif.

22. (+)-Camphor was typically recovered, after filtration of the crude material through a Seppak cartridge and evaporation of the solvent, and showed an optical rotation value of $[\alpha]_{\mathrm{D}}{ }^{25}$ $=+41.5(\mathrm{EtOH}, c=1.0)$ (Measured value for the starting camphor, purchased from Acros $\left.[\alpha]_{\mathrm{D}}^{25}=+42.2(\mathrm{EtOH}, c=1.0)\right)$.

23. (a) Stratmann, K.; Burgoyne, D. L.; Moore, R. E.; Patterson, G. M. L. J. Org. Chem. 1994, 59, 7219. For synthesis, see: (b) Dinh, T. Q.; Du, X.; Armstrong, R. W. J. Org. Chem. 1996, 61, 6606. (c) Ghosh, A. K.; Liu, W.; Xu, Y.; Chen, Z. Angew. Chem., Int. Ed. 1996, 35, 74. (d) Palomo, C.; Oiarbide, M.; García, J. M.; González, A.; Pazos, R.; Odriozola, J. M.; Bañuelos, P.; Tello, M.; Linden, A. J. Org. Chem. 2004, 69, 4126 and referentes therein.

24. Hermann, C.; Pais, G. C. G.; Geyer, A.; Kühnert, S. M.; Maier, M. E. Tetrahedron 2000, 56, 8461.

25. Adapted from Hung, S.-C.; Wen, Y.-F.; Chang, J.-W.; Liao, C.-C.; Uang, B.-J. J. Org. Chem. 2002, 67, 1308.

26. Adapted from Wilkinson, H. S.; Grover, P. T.; Vandenbossche, C. P.; Bakale, R. P.; Bhongle, N. N.; Wald, S. A.; Senanayake, C. H. Org. Lett. 2001, 3, 553.

27. Compound $\mathbf{1 6}$ was prepared starting from (1S)-(-)-camphor by following the same procedure employed for the preparation of 5 from the (1R)-enantiomer. 